\title{
The Legion of the Lost. Recovering the Lost Books of Early Modern Europe
}

\author{
Andrew Pettegree
}

For students of material bibliography the issue of lost books - by definition immaterial - is inherently problematic. It is universally agreed that autopsy, the examination of the copy, book in hand, represents the gold standard of bibliography. Many highly valued bibliographical projects, such as the Dutch Short Title Catalogue Netherlands (STCN) or the Belgian Short Title Catalogue Vlaanderen (sTCV), do not deviate from this standard; their repertories consist only of books examined by members of their team. Major collective catalogues, such as the KVK or CERL's Heritage of the Printed Books, apply essentially the same methodology, though here the inspection is delegated to participating libraries. These are catalogues (or more properly metaopacs) in which editionspecific entries are invariably connected to surviving copies.

This stress on materiality synchronises with other important trends in the development of book history, a relatively young field that has made enormous strides in recent times. Book historians have developed their discipline in the last three decades by insisting repeatedly that the book is more than a mere repository of text; that to understand its place in the economy of knowledge it is necessary to take account of the manufacturing process, the typographical set-up, the physical appearance and layout of early books. Against the onward rush of digital editions they had argued that it is really is necessary to have the book in hand, the physical artefact, to understand print. To have carried the day in arguments within the discipline and then to have this undermined by a quixotic appeal to incorporate into the narrative books that no longer exist this might seem perplexing and paradoxical.

But consider this. The rate of survival of many early printed books is very low. The best and most well-known books, like the Gutenberg Bible, Shakespeare's First Folio or early editions of Copernicus survive in large numbers. ${ }^{1}$ They are valuable but not rare. By a strange inversion of value and rarity, books which

1 Gutenberg's Bible survives in 48 full or partial copies, an estimated $30 \%$ of the original print run; the De revolutionibus of Copernicus is known in 277 copies today, and Shakespeare's First Folio in 233. The magnificent Nuremberg Chronicle, one of the most spectacular books of the first age of print, survives in over 500 copies. 
command a much lower sale value can be very rare indeed. How little this relationship between rarity and value is understood was beautifully illustrated by the New York Times, reporting the discovery in 2014 of a previously unrecorded copy of the Shakespeare First Folio: "First folios of Shakespeare's plays are among the world's rarest books", it claimed, totally inaccurately, as was demonstrated a few lines further down the same article. "Now a previously unknown folio has surfaced at a small library in northern France, bringing the world's known total of surviving First Folios to 233". ${ }^{2}$ Though this is indeed an exciting discovery, the First Folio is one of the least rare, rather than the rarest of early printed books.

The reason for this disjunction lies in the history of how books published in the early years of print were treated in the years immediately after publication. Unlike the First Folio, which was much prized by contemporaries, many printed works published in the first two centuries of print were never destined for the shelves of libraries. They served their purpose, were read for the information they contained, and then discarded. Many are known now from only a single copy, often grubby and worn. This applies, as we shall see, to around $30 \%$ of the known corpus of books printed before 1601 . It is fairly obvious that if we know of many of these books only through the chance discovery of a single stray survivor, often in a library far distant from the original place of publication, then many other early editions must be lost altogether.

The logic of this was expressed with brutal clarity by Paul Needham, the distinguished historian of early print now at Princeton. The first edition of the collected works of St Ambrose was published in Basel in 1492. It survives in more than 150 copies. This is the only recorded edition of Ambrose in the fifteenth century, and in the light of its very high survival rate, one can be fairly confident in asserting that there were no other early editions which have disappeared. By contrast, six fifteenth-century editions are currently known of the popular French chivalric romance Paris et Vienne. One edition is recorded in two copies, the remainder are known by a single copy each. Given such a pattern, it is highly likely that other editions were printed and have failed to survive. "Indeed", writes Needham,

if one wanted to believe that only these six known editions of Paris et Vienne were printed before 1501, one would almost have to suppose that an all-seeing fate intervened when each of the editions was almost lost and lent a special protection to the last survivor. ${ }^{3}$

2 'Shakespeare First Folio Discovered in France', New York Times, 25 November 2014.

3 Paul Needham, The Printer and the Pardoner (Washington: Library of Congress, 1986), p. 30. 
The logic is unanswerable, though precisely what we should do with this information is rather less clear. It is not unusual for scholars to acknowledge the potential absence of many currently unknown editions; then, having done so, analysis proceeds, as before, on the basis of surviving copies. Here the difficulty of dealing with the immaterial is laid bare: is there in fact any alternative to relying of the evidence we have to hand, in the corpus of books assembled in the world's libraries? Might this in fact be the best way to proceed, recognising the high attrition rate as one of the inconvenient truths of book scholarship simply acknowledging the disappearance of this vast shadow army of lost books as an unavoidable fact of historical scholarship, recognisable but ultimately not susceptible of correction?

Why does this even matter? There are many reasons to argue that if we are to assess the impact of publishing on the culture and economy of Europe, we have to base these conclusions on a more holistic sense of what was published, rather than merely what libraries have preserved. This is even more the case because it is clear that the rates of survival and loss are very uneven across different types of printed book. The sorts of books that survive best are those that were destined for libraries. These were generally books that were large, tended to be more expensive, and were more likely to be in Latin. They were bought, admired, and then made their way onto the library shelves. They were not necessarily widely read: indeed many such books were primarily intended for reference rather than consecutive reading. Some were bought because it was unthinkable that a prestigious institution would not have a copy of an important text like Calepino's multi-language dictionary. ${ }^{4}$ In these cases the individual copies have probably survived so well, often in pristine copies, precisely because they were not extensively used.

Facing this uncomfortable paradox - that the best surviving books from the first age of print may indeed have been the least well used - is the spur to a more systematic attempt to grapple with issues of survival and loss. In this volume, and in the underpinning work that lies behind it, contributors have attempted to cast light on that part of the market for print most vulnerable to loss and disappearance. And once you acknowledge the necessity of this sort of enquiry, it is in fact much easier to make some progress than the paradoxical nature of documenting the invisible might suggest. At last, the tools are to hand.

Here, scholarship has undoubtedly received an enormous boost from the free availability of digital catalogues, enabling scholars to obtain access to

4 Albert Labarre, Bibliographie du dictionarium d'Ambrogio Calepino: (1502-1779) (Baden-Baden: Koerner, 1975). 
hugely increased quantities of data from the world's libraries, archives and museums. Much of this is aggregated into the Universal Short Title Catalogue, a transnational survey of works published throughout Europe in the first age of print. ${ }^{5}$ When we announced that 'Lost Books' would be the theme of the latest in the sequence of annual conferences on the history of the book that the project team hosts in St Andrews, it attracted far more paper proposals than could comfortably be accommodated. That we should reach this subject was something of an inevitability given the direction of travel of the USTC, where we have systematically recorded information on lost books since our first years working on French materials. But that the announcement of the subject found such a resonance, indicates I think a real evolution in thinking as scholars in the field begin to grapple with the implications of the great mass of information now available in the digital age, and its potential as a tool of analysis.

The contributions marshalled here suggest a variety of possible approaches to the issue. One is to design statistical models that offer estimates of the extent of losses for the population as a whole within specific time periods or geographical areas. ${ }^{6}$ This approach has already produced some of the more interesting, though mathematically challenging work. The second approach is to examine contemporary documentation of the book trade, print and archival, and see what lost editions can be recovered in this way. This sort of bibliographical archival work has a long history, and editions that cannot be linked to a surviving copy have, in this way, routinely been incorporated into specialist bibliographical works. This sort of recovery from contemporary documents has also been a major focus of the work of the St Andrews USTC project group, leading to the incorporation of several thousand such lost books into the online resource. A third approach is the recreation of contemporary libraries, a rich strand of research in the history of the book well represented in this volume.

\section{Statistical Modelling}

In the last years there have been several attempts to investigate this question of loss in a systematic way, aimed at computing the number of editions at present undiscovered for different samples of texts. Some of these involve

$5<$ http://ustc.ac.uk/>. The USTC initially covered the first 150 years of print, to 1601 ; coverage was extended to 1650 in 2016.

6 Goran Proot, 'Hoe volledig zijn de STCN en de stcv?', in Edwin Bloemsaat et al. (eds.), Janboel. Opstellen aangeboden aan Jan Bos (The Hague: 2009), pp. 123-132. 
mathematical models of great sophistication; others a simpler method known as zero graphing. Zero graphing has the beguiling advantage that conceptually and mathematically it is straightforward. It is necessary, first, to have a sufficient sample, based on a relatively comprehensive search for surviving copies. With that achieved one can plot the distribution of surviving copies of every edition, ten or more down to three, two and one. By extrapolating the graph line to zero, a projection is achieved predicting how many editions do not survive at all. A more sophisticated, cautious variation is to limit the projection to the first two points, for one and two copies, which offers a flatter curve so a lower estimate for zero.

The first analysis using such a technique was offered by Neil Harris, an imaginative pioneer in this and other fields of analysis. His corpus was a survey of Italian chivalric romances, an extraordinarily popular genre, and one that one might imagine would be subject to heavy attrition through use. Harris identified 377 surviving editions published before 1601, one of which, the 1572 edition of the Ciriffo Calvaneo, survives in an impressive 108 copies. At the other end of the scale, 36 editions survive in 3 copies, 73 in 2 and 206 in one copy. Here a projection based on zero-graphing would suggest something in the region of 600 lost editions, that is, nearly twice the number of documented survivors. ${ }^{7}$

A similar survey had been attempted more recently with a rather larger corpus, French-language books published over the period $1470-1600 .{ }^{8}$ The keystone of this project was a prolonged period of investigation, incorporating data from over 300 libraries in France and many more abroad; this work outside France was crucial, and differentiated this project from other national bibliographies such as Edit16 and the VD16, which by and large include data only from participating libraries within their own national domain. The virtue of the wider search conducted for France was revealed by the fact that of the French editions, around 30 per cent survive only in libraries outside France. Dealing then with a corpus of around 52,00o editions, the data for France revealed that 4,521 editions survive in three copies, 8,165 in two and a remarkable 21,119 ( $40 \%$ of the total) in one copy. ${ }^{9}$ Basing the projection on the last two

7 Neil Harris, 'The Italian Renaissance Book: Catalogues, Censuses and Survival', in Malcolm Walsby and Graeme Kemp (eds.), The Book Triumphant. Print in Transition in the Sixteenth and Seventeenth Centuries (Leiden: Brill, 2011), pp. 26-56, at pp. 54-55.

8 Andrew Pettegree, Malcolm Walsby and Alexander Wilkinson, FB. French Vernacular Books. Books Published in the French Vernacular before 1601 (Leiden: Brill, 2007). The results are now incorporated into the Universal Short Title Catalogue, available online: <http://www.ustc .ac.uk/>.

9 As reported in Harris, 'Italian Renaissance Book', pp. 53-54. 
data points suggests 59,00o lost editions; following the curve of the graph gives a far higher figure.

A further extrapolation, presented with far more sophisticated mathematical underpinnings, is provided by a milestone survey of incunabula conducted by Jonathan Green and Frank McIntyre, contributors to this volume, in an earlier piece of research co-authored with Paul Needham. ${ }^{10}$ Dealing with a total population of 28,767 editions published throughout Europe in the fifteenth century, they found 2,039 surviving in three copies, 3,217 in two copies, and 7,488 in one copy only. The conservative calculation based on the last two graph points offers a total of around 20,000 lost editions.

Of course it is by no means obvious that the results from a survey of fifteenth century survivors can stand as typical for the whole early modern period. Incunabula were regarded as collectable from the time of their first publication onwards, so they were far less likely to be subject to the brutal attrition of more mundane print in later years. The contribution of Falk Eisermann in this volume demonstrates there is still a great deal to be said about incunabula editions that have not yet found their way into the online ISTC. What we can note, however, as a common feature of all these attempts to gauge the real size of discreet populations of production, is the very steep upward curve between two and one copies. We will never, through this method aspire to exact calculations for lost editions, but for all the models so far attempted the number is clearly very large, and most likely increasing, rather than decreasing, in the course of the sixteenth and seventeenth centuries, and even beyond.

Here the most sobering study is that conducted by Goran Proot and Leo Egghe, estimating the total original production of Jesuit play programmes. Since these were printed to be distributed free of charge to those who attended such performances, the scale of loss is bound to be very large, in this case spectacularly so. Proot and Egghe estimate three editions lost for every survivor. ${ }^{11}$ This seems very plausible for ephemeral works of this type, which seldom survive in more than one copy. But it is also the case that with ephemera of this sort, the assiduous efforts of one collector may have a significant influence on any statistical analysis, particularly in cases like this where a single bound

10 Jonathan Green, Frank McIntyre and Paul Needham, 'The Shape of Incunable Survival and Statistical Estimation of Lost Editions', Papers of the Bibliographical Society of America, 105 (2011), pp. 141-175.

11 Goran Proot and Leo Egghe, 'Estimating Editions on the Basis of Survivals: Printed Programmes of Jesuit Plays in the Provincia Flandro-Belgica before 1773, with a Note on the "Book Historical Law"', Papers of the Bibliographical Society of America, 102 (2008), pp. 149-174. 
volume might represent a considerable proportion of the whole corpus of surviving copies. In this volume Goran Proot continues this strand of analysis, demonstrating the significant role played by such bound volumes, Sammelbände, in the survival of small books. ${ }^{12}$ What this article also brings home is that the loss or survival of early printed books is likely to be very genre specific: some types of books are far more likely to survive than others. If we turn away from our algorithms and examine other contemporary sources for the disinterring of lost books, this becomes ever more evident.

\section{Serials}

Let us begin with someone with whom I have become quite closely acquainted in the last years, Abraham Verhoeven of Antwerp. Verhoeven was in some respects a rather disreputable man, prone to fighting, whose career was bedevilled by a long and debilitating struggle with his wife and in-laws. But he was also a highly original and innovative publisher, turning his early training as an engraver and woodcut artist to good effect with a series of highly successful news broadsheets. These are worthy of study in their own right, but the principal interest of Verhoeven for our purposes today is that he was the purveyor of Antwerp's first regular news serial. The online bibliography for Belgian publishing, the STCV, has 398 entries for Verhoeven, but by chasing these fugitive news periodicals around the various holding collections I have built this up to $2,146 .{ }^{13}$

The fun starts when Verhoeven begins to number as well as date his serials. Of the two thousand surviving items well over half can be traced in only one copy. Some are clearly lost altogether. But if the issue of 3 February is numbered 15, and that of 12 February number 17 , I think we can, without reaching too far into the realms of speculation, assume the publication of a now lost number 16. So that is what we have done. This technique has resulted in the addition of at least 150 books to the bibliography for Verhoeven, for items now lost but plausibly assumed to have been published. But how far can you go? For some of the earliest provincial English newspapers the first known issue appears to date from some time into the run. The first

\footnotetext{
12 Chapter 8, below.

13 Data collected for the planned extension of the USTC to 1650, accessed 7 October 2015. See also Andrew Pettegree, 'Tabloid Values. On the Trail of Europe's First News Hound', in Richard Kirwan and Sophie Mullins (eds.), Specialist Markets in the European Book World (Leiden: Brill, 2015), pp. 17-34.
} 
known issue of the Bristol Post-Boy is number 91 of 12 August 1704, suggesting that if the paper followed a regular weekly pattern the first issue would have been published two years earlier. The next issue to have survived is number 281 of 20 March 1708 . For the Norwich Post we have no issue before number 287 of 3 May 1707. The only surviving issue of the Exeter Post-Man is number 556, from 10 August 1711, suggesting that this, with regular weekly editions, would actually have preceded these other early papers with a first issue in December $1700 .{ }^{14}$

This low level of survival is not at all unusual. We know of early newspapers, documented from other sources, for which not a single issue survives. ${ }^{15}$ How should we treat these serials bibliographically? Should these stray survivors generate a vast shadow army of issues - books - presumed to have existed?

There is, in fact, a strong argument that they should, not least because these missing issues would have represented a high proportion of the total printing output of many presses; this was sometimes particularly the case in small provincial towns where a printing press teetered on the brink of unviability. And what is the alternative to assuming these lost issues did actually at one time exist? It is hard to predicate a plausible reason why a printer should start a new venture with a mythical claim to previous issues. Where the first issue of a news serial does survive we see that it is normal to begin with some sort of editorial statement of purpose coupled with an invitation to new subscribers. It would go against all business logic to tease the reader with the claim to have printed several hundred issues that did not in fact exist. Numbering served as a prompt to purchasers to send to the office for back numbers, so that they had a complete back run. To invent a mythical pre-history would have served only to irritate subscribers who had to be wooed and conciliated. So we are inclined to believe that these early lost issues did once exist. The lost, but presumably once existing issues can play an important part in helping us comprehend the economics of regional presses, which are otherwise responsible only for a very small number of identifiable works.

14 R.M. Wiles, Freshest Advices. Early Provincial Newspapers in England (Columbus: Ohio State, 1965), pp. 14-16.

15 For a Rotterdam newspaper from the 1680 s known only from archival references and an English translation see M.M. Kleerkooper, 'De Haarlemsche (en de Rotterdamsche) courant in het Engelsch', Tijdschrift voor Boek- en Bibliotheekwezen 4 (1906), pp. 99-107 and W.P. Sautijn Kluit, 'De Rotterdamsche Courant', Jaarboek van de Maatschappij der Nederlandse Letterkunde, 1878 (Leiden, 1878), pp. 3-92. The erratic survival of early German newspapers can be followed in Else Bogel and Elgar Blühm, Die deutschen Zeitungen des 17. Jahrhunderts. Ein Bestandverzeichnis (2 vols, Bremen: Schünemann, 1971). 


\section{Cheap Print}

Early printed books that survive in large numbers do so essentially because they were destined for libraries. They by and large served the needs of scholars, and were therefore often in the scholarly languages. Their chances of survival were improved because use diminished over time; either they were superseded by other more modern texts, or particularly in the case of Latin books, the shift towards vernacular reading rendered them increasing redundant. Once they had reached the safety of institutional collections they were not, on the whole discarded, their antiquity providing a measure of protection; but neither were they heavily consulted. Nevertheless, they remain, often in considerable numbers, the staples of many rare book collections.

The publication of books of this sort was not particularly profitable for printers; indeed they often lost money on prestige projects. ${ }^{16}$ The sorts of works that delivered steady profits were usually the unregarded pamphlets, broadsheets and printed ephemera that were never intended to dignify the shelves of a library. They were intended for use: and that of course impacted in a negative way on their chances of surviving through to the present day. The thousands of early printed books that survive in only one copy very often fall into this category: usually small formats, often (though not invariably) printed in vernacular languages. Printed works of this sort survive, if they do, only by chance or thanks to the eclectic collecting of someone who would at the time have been regarded as deeply eccentric.

This sort of cheap print was the real economic backbone of the industry, and has attracted a lot of interest in recent years. A great deal of this material was printed on commission for the local power, civil or ecclesiastical. Printers eagerly sought out opportunities to act as the official printer to the local city, ecclesiastical or state authorities, for the privilege to print official mandates was the nearest thing possible to a licence to print money. ${ }^{17}$ These were perfect assignments for a printer: the whole job took only a couple of days, they were usually paid cash and the whole edition was delivered to a single customer. In the first age of print the equivalent was printed indulgences: indulgences were among the first works published by Gutenberg, and they continued to provide easy profits for the next sixty years, right up to the first

16 Ian Maclean, 'Murder, Debt and Retribution in the Italico-Franco-Spanish Book Trade: The Beraud-Michel-Ruiz Affair, 1586-1591', in his Learning and the Market Place (Leiden: Brill, 2009), pp. 227-272.

17 Lauren Kim, 'French Royal Acts Printed before 1601. A Bibliographical Study' (St Andrews PhD dissertation, 2007). 
decade of the Reformation. ${ }^{18}$ The quantities involved were quite vast. We know of two examples documented from surviving contracts which make the point in a very graphic way. Between 1498 and 1500 the great Benedictine convent of Montserrat in Catalonia commissioned the printing of more than 200,000 indulgences, from different printers in Barcelona and Montserrat itself. Of these 200,000 only 6 examples survive. Similarly in 1500 the Bishop of Cefalù in Sicily commissioned a Messina printer to print 130,000 indulgence certificates. Not one single example survives today. ${ }^{19}$

We can easily understand why printers were attracted to work of this sort. There were none of the problems and expense involved in meeting the complex challenges of distribution, exchange, warehousing and transportation that were bound up with the publishing of large books. Only the largest and best capitalised firms could print large books, whereas even the modest enterprise could print a broadsheet or brochure. But this does not imply that this sort of work was usually consigned to smaller shops. What is becoming increasingly clear is that even the publishers who were responsible for the most ambitious ventures also eagerly sought out opportunities to bring out ephemeral print. ${ }^{20}$ Often it provided them with the means of generating cash flow while the larger books went through the press; authors learned to be vigilant that their own cherished project was not unceremoniously laid aside in this way. ${ }^{21}$ For a big book it might be as long as 18 months between beginning the work and having complete books to sell, and another 18 months before they had recouped costs and began to show a profit. That was three years of fixed costs, wages, interest payments and equipment costs. That was a large burden and only the most heavily capitalised firms could contemplate it. A pamphlet could be printed in two days and show a profit in a week. It is no surprise then if we now believe that it was this hidden underbelly of ephemeral publishing that floated the printing industry, rather than the more elevated texts that so excited the first historians of the printed book. ${ }^{22}$

18 Albert Kapr,Johann Gutenberg. The Man and His Invention (Aldershot: Scolar Press, 1996), pp. 189-197. Hans Volz, 'Der St. Peters-Ablass und das Deutsche Druckgewerbe', GutenbergJahrbuch, 1966, pp. 156-172.

19 Paul Needham, The Printer and the Pardoner (Washington: Library of Congress, 1986), p. 31.

20 Dirk Imhof, Jan Moretus and the Continuation of the Plantin Press (Leiden: Brill/HEs \& De Graaf, 2014).

21 Jan Machielsen, 'How (Not) to Get Published: The Plantin Press in the early 159os', Dutch Crossing, 34 (2010), pp. 99-114.

22 Andrew Pettegree, The Book in the Renaissance (London: Yale, 2010). Joad Raymond, Cheap Print in Britain and Ireland to 1660 (Oxford: Oxford University Press, 2011). 


\section{Into the Archives}

Discovering what became of such ephemeral works, however, is a very different matter. Broadside ordinances were meant for public exhibition; they were usually left on the church or town hall door until destroyed by wind and rain. If they have survived at all it was usually because the issuing authority (or in Plantin's case, the printer) kept a file copy. ${ }^{23}$ In consequence such broadsheet survivors will more usually be found today located in archives rather than libraries, often uncatalogued: a lot of work still needs to be done to document fully those preserved in this way and as Saskia Limbach shows in this volume, the search can be both intricate and venturesome. ${ }^{24}$ Sometimes they are clearly lost altogether: we are only aware that they were ever printed because the text was transcribed into a local archival record of ordinances and decrees, or because the city accounts recorded a payment to the responsible printer. ${ }^{25}$ Archival records, as it turns out, represent another very fruitful source of lost books.

In 1617 Abraham Verhoeven received a valuable commission, so lucrative indeed that it might have alerted his fellow Antwerp printers to Verhoeven's access to the sort of official patronage which later landed him the lucrative monopoly in news. In this year he was commissioned to print 100,000 copies of the list of prizes to be offered in a forthcoming lottery. The contract stipulated different versions in six separate languages. Of this mass of print, only three items survive: one copy of the Spanish version, and two of the French. ${ }^{26}$ So we can infer the existence of four further lost editions.

Archival records of this sort - particularly contracts or registration of payments in city accounts - provide quite a rich harvest of books commissioned but no longer surviving. Overwhelmingly these relate to official print, or works commissioned by the local ecclesiastical authorities. Much of this sort of

23 For Plantin's production of ordinances for the local authority see Leon Voet, The Plantin Press (1555-1589). A Bibliography of the Works Printed and Published by Christopher Plantin at Antwerp and Leiden (6 vols., Amsterdam: Van Hoeve, 1980-1983), I 68-569. Moretus Continued the Practice: see Imhof, Moretus, pp. $745^{-878}$.

24 Chapter 24, below.

25 See for instance Karl Härtner and Michael Stolleis (eds.), Repertorium der Policeyordnungen der Fuhen Neuzeit (10 vols., Frankfurt: Klostermann, 1996-2010). Frustratingly these volumes do not always systematically record whether the individual items recorded are print or manuscript.

26 Blanco o Loteria general, que se instituye en la villa de Brusselas, para elmonte de Piedad (Antwerp: Verhoeven, 1617). Brussels Royal Library. Blanques ou lotheries generals (Antwerp: Verhoeven, 1617). Brussels ARB, Washington, Folger Library: 183551. 
jobbing work was never intended for commercial sale, but either to be exhibited or distributed for information purposes. This non-commercial print was a part of the market that is only just beginning to attract sustained attention, but it obviously was extremely important for printers for whom it was very commercial indeed. This remained true far beyond the first age of print. Jane McLeod, in her powerful study of French provincial printing in the Ancien Régime, demonstrates how the title of printer to the city council, bishop or king was bitterly contested in many French towns, where it was not only very lucrative work but often the only work. ${ }^{27}$

This was brought vividly home to us in an early stage of our French work, when we came across an account book in the city archives of Bourges, featuring a series of payments to a printer active in the town. ${ }^{28}$ The payments, for a sequence of local reprints of royal edicts, were remarkably generous, and the editions relatively large. But not a single one of any of these imprints has yet materialised in any library or archive. But for the survival of these registered payments, we would know nothing of this printer at all, since these are his only known publications.

\section{Book Trade Records}

These archival discoveries are all the more important because the rate of survival for French single-sheet printing is very poor. There is nothing like the magnificent series of file copies retained by Christophe Plantin in his Antwerp office. Plantin seems to have kept one or more copies of every official edict he published, which makes this the most marvellous treasure trove for any historian interested in the expanding role of government in the sixteenth century. ${ }^{29}$ But even in the meticulously documented Plantin workshop there were some books that cannot be traced today: as we know from the equally meticulous Plantin accounts. Here he documents the production, the print runs and the despatch of all his projects, and these include a handful of books that have completely disappeared. Mostly the lost books of the Plantin press are either small format educational texts - ABC books - or devotional texts. These are types of books that have exceptionally poor survival rates, precisely because

27 Jane McLeod, Licensing Loyalty. Printers, Patrons and the State in Early Modern France (University Park: Pennsylvania State University Press, 2011).

28 Archives municipales of Bourges, CC 349-CC 646. See Répertoire bibliographique du livre du seizième siècle, vol. 13 (Bourges).

29 Voet, Plantin Press, nos. 121-563. 
they were so intensively used. For England we know of one ABC book authorised for publication in an edition of 10,000 copies, of which not one single copy survives. ${ }^{30}$

But in terms of volume these opportunistic rediscoveries are less significant than the relatively large number of currently unknown books that can be recovered from contemporary published book-lists. Here a special place must be reserved for the rather grand encyclopaedic projects that aspired to document the entire learning of a particular era or country. Two of these were published in France: the Premier volume de la bibliotheque of François de la Croix du Maine (1584), and Antoine du Verdier's La bibliotheque (1585). These books themselves are not rare at all: they adorned the shelves of so many libraries they may be regarded as virtually a compulsory purchase to anyone aspiring to create a serious collection, or indeed to celebrate the cultural achievements of the French nation. But included in du Verdier's pages are a considerable number of books that can no longer be traced. Given that du Verdier was working from physical copies or data supplied to him by friends in the trade, it can by and large be assumed that these references are relatively reliable. ${ }^{31}$

The very best lists, and a source still ripe for investigation, are the registers of the Frankfurt Book Fair. From 1564 an enterprising Augsburg bookseller published, for every fair, a list of the recently issued titles that publishers intended to offer for sale. ${ }^{32}$ In many cases, since this was a service mainly for other publishers and booksellers that might be expected to buy wholesale, these lists included the printer, place of printing and format. And yet there has been no systematic analysis of which of the items offered for sale can be linked to a surviving copy. When I examined the limited number of French titles sold at Frankfurt over a period of some twenty years I found that around $10 \%$ cannot now be paired with a surviving book. ${ }^{33}$ But these French titles were a tiny proportion of the books sold at Frankfurt. For anyone looking for a subject that takes them to the heart of the European book trade this, I think, offers huge potential.

The Frankfurt Fair catalogue is by far the most famous, but by no means the only such collective catalogue generated from within the book trade. In 1639 the

30 H. Anders, 'The Elizabethan ABC and the Catechism', The Library, 4th ser., 16 (1935), pp. $32-48$.

31 Alexander S. Wilkinson, 'Lost Books Printed in French before 16o1', The Library, 7th ser., 10 (2009), pp. 188-205.

32 The whole sequence of catalogues for the period ${ }^{1564-1600}$ is available as a facsimile reprint: Bernhard Fabian, Die Messkataloge des sechzehnten Jahrhunderts (5 vols., Hildesheim, 1972-2001).

33 Andrew Pettegree, 'French Books at the Frankfurt Fair', in his The French Book and the European Book World (Leiden: Brill, 2007), pp. 129-176. 
Amsterdam printer Broer Jansz used his newspaper to ask other publishers to send details of their new works to him, so that he could create a bi-annual list of books published in the Dutch Republic. The Republic was by this point one of Europe's major centres of publication, so this was a large task, but Broer Jansz persevered, and the catalogue duly appeared..$^{34}$ Broer Jansz maintained this venture until his death thirteen years later, publishing his lists on a bi-annual and then annual basis. Like the Frankfurt Book Fair Catalogue, this list has never been analysed to see whether all of these items could be identified from surviving copies.

Broer Jansz was the proprietor of one of two weekly newspapers in Amsterdam, both published on Saturdays, the other by his long-term competitor Jan van Hilten. ${ }^{35}$ These two imaginative publishers were the first to include paid advertisements in their papers on a systematic basis, a crucial innovation that would in time come to underpin the finances of the newspaper industry, and free it from dependence on subsidies from the local state authorities. In the first decades after Broer Jansz and van Hilten began to include advertisements, these were almost always for newly published books. To this point noone has yet made a systematic study of these advertisements, or attempted to link them to surviving copies of the books concerned. The records are, in fact, extremely well adapted to this purpose: each advertisement gives a full version of the title, together with details of the publisher; and they can generally be assumed to have been published close to the date of the newspaper in which they were advertised. Even so, a remarkably high proportion cannot presently be linked to any known surviving copy. To this point around a third of the titles thus far examined are lost books. If this trend were to be maintained for the entire seventeenth century, it would result in the addition of over 1,60o items to the Dutch national bibliography. ${ }^{36}$

\section{London}

With these excellent records we finally approach one other potential book industry cornucopia of data, the records of the Stationers' Company of London.

34 H.W. de Kooker (ed.), The Catalogus Universalis of Broer Jansz (1640-1652). A Facsimile Edition of the Dutch Booktrade Catalogues Compiled and Published by Broer Jansz, Amsterdam, 1640-1652 (Leiden: Hes \& De Graaf, 1986).

35 Arthur der Weduwen, Dutch and Flemish Newspapers of the Seventeenth Century, 1618-1700 (Leiden: Brill, 2017).

36 Arthur der Weduwen and Andrew Pettegree, News, Business and the Birth of Modern Advertising. Advertisements and Public Announcements in Dutch and Flemish Newspapers, 1618-1672 (Leiden: Brill, 2018). See also Chapter 9, in this volume. 
In England, uniquely in Europe, the regulation of output and production was sub-contracted to a private body: in this case a city guild, the Stationers' Company. Those wishing to publish a book could for a fee register new titles, which should then protect them from predatory editions undertaken by other brethren in the trade. ${ }^{37}$ This was the equivalent of the privilege system which operated in other parts of Europe, which was intended to guarantee that anyone investing in the costs of a new text, translations and so on, could be assured of a reasonable return on their investment.

The London trade was small and close-knit, policed by the privileged few who made up the masters of the Company, so the chances of going undetected in the publication of unauthorised or pirate editions was small enough to discourage flagrant abuse. ${ }^{38} \mathrm{Of}$ course, like all sixteenth-century systems of regulation, the system worked better in theory than in practice. Many books were published without being entered in the Stationers' Register. But in other cases, indeed, as Alexandra Hill shows in this volume, many thousands of cases, titles were registered which cannot now be linked to a surviving copy. ${ }^{39}$

This has been recognised by students of the English print trade for a considerable time, without anyone making systematic use of this potential goldmine of information. ${ }^{40}$ Some important scruples lie behind this reticence. It could be argued that the fact that a printer registered a title with the Stationers' Company does not provide proof positive that it was ever published. This is true. One could imagine that a publisher might wish to forestall a rival, or indeed to be planning to publish a book and for one reason or another - a failure to raise the necessary funds, or second thoughts about whether there was sufficient demand - simply abandon the project.

But these considerations are likely to apply only in a small number of cases, and generally speaking for larger books, the sort for which continental publishers would generally seek privileges. In these cases the effort and relatively small cost of registering a book might be a reasonable contingency expense in the larger framework of publishing a book of any size. Most of the unknown books in the Stationers' registers were not of this character at all. They were small books or broadsheet ballads: the type of printed artefacts for which survival is in any case very fragile.

Edward Arber (ed.), A Transcript of the Registers of the Company of Stationers of London, 1554-1640 (5 vols., London: Privately printed, 1875-1894).

38 For the colourful and bruising career of a serial pirate see Alexander Rodger, 'Roger Ward's Shrewsbury Stock: An Inventory of 1585', The Library, 5 th ser., 13 (1958), pp. 247-268.

39 Below, Chapter 7.

40 See, for instance, Cyndia Clegg, Press Censorship in Elizabethan England (Cambridge: Cambridge University Press, 1997), pp. 18-19. 
It is very hard to see why a printer would have gone to the trouble of registering a ballad and then not publish it. This was the sort of book where immediacy was of the essence. It was intended to catch a moment of particular interest for a contemporary event; it could be put to the press and out onto the streets in a single day. ${ }^{41}$ There was no great investment in paper or wages to be protected. Furthermore it is hard to see how registration of a then unpublished ballad would forestall a potential competitor: they could simply publish the same text under a different title. So the overwhelming likelihood is that ballads registered in the Stationers' Company, often with very precise titles, were indeed published, and are now simply lost. We intend in the next two years to integrate these references into the USTC, searchable in exactly the same way as surviving books. It will be the largest injection of new data into the corpus of early British printing for the best part of forty years, and it should have a significant impact on our understanding of the functioning of the industry. ${ }^{42}$

\section{Censorship}

Other published book-lists come in three main types. A printer might publish in the back of a book a list of other works he had published, or works by the same author. A bookseller might exhibit a list of books available from his shop. ${ }^{43}$ And the church or state might publish lists of books that its citizens were forbidden to buy, sell or even to possess.

This last category is especially interesting, because it brings into our study books that are not lost through use or casual discarding, but because they were purposefully destroyed. Non-survival in this case is not an accident of history, but a deliberate act of policy. So this information should be especially valuable. Some parts of these lists are of course more valuable than others. An index of forbidden books that states that all the works of a stated author - Calvin or Rabelais - are forbidden, does not take us much farther forward. But some entries on these lists are remarkably specific: particularly, as is often the case,

41 See, for examples taken from Armada year, 1588, Bertrand T. Whitehead, Brags and Boasts. Propaganda in the Year of the Armada (Stroud: Alan Sutton, 1994).

42 Since publication of the second volume of the revised edition of the STC, in 1986.

43 The fundamental study is G. Pollard and A. Ehrmann, The Distribution of Books by Catalogue from the Invention of Printing to A.D. 1800 (Cambridge: Roxburghe Club, 1965). Andrew Pettegree, 'Emden as a Centre of the Sixteenth-Century Book Trade: A Catalogue of the Bookseller Gaspar Staphorst', in his The French Book and the European Book World (Leiden: Brill, 2007), pp. 177-201. 
when they deal with anonymous tracts of an evangelical character. Here the list often gives the title verbatim. The edict is clearly set up with copies of the proscribed books in hand. These would then, presumably, be destroyed: an early example of the practice of material bibliography, if with a somewhat malign intent. ${ }^{44}$

The same desire to deny readers access to disapproved texts that stimulated the published Indices of Forbidden Books also left its imprint on the manuscript sources. When a bookseller came under suspicion, it was not unusual to send another loyal and orthodox member of the trade into their shop to work their way around the shelves, noting the titles. ${ }^{45}$ This provides some fantastic material for historians of the book trade, though it is not necessarily a particularly rich source of lost books. In cases of this sort there was a pronounced tendency towards obfuscation: the assessing bookseller, who might be a close friend of the colleague under suspicion, might well allow his gaze to slide past articles in the stockroom that would bring serious consequences if included in the inventory. With so much at stake it was hard to ensure that the inspectors carried out their duties punctiliously. The same can be said, for rather different reasons, of the audit of stock taken at the death of a bookseller or printer, or as a result of a legal dispute between two book trade professionals. Here, where the emphasis was entirely on making an estimate of stock value, there was no imperative to gather more information than necessary to serve this narrow economic purpose.

But the investigation of orthodoxy does offer one potentially very rich harvest of information, though it must be used with delicacy and real care. Towards the end of the sixteenth century the leaders of the Church in Italy began tightening the screw on the sale and ownership of unorthodox books. They were particularly concerned lest members of the monastic communities be led astray. All local religious authorities were required to send in lists of any banned materials in the possession of those under their jurisdiction. This particular initiative turned up predictably little; local authorities were understandably reluctant to call down trouble upon their heads, and could take

44 See Jesús Martínez De Bujanda, Francis M. Higman and James K. Farge (eds.), Index de l'Université de Paris: 1544, 1545, 1547, 1549, 1551, 1556 (Sherbrooke, Québec: Université, Centre d'Études de la Renaissance - Geneva: Droz, 1985) and others in this series of modern editions of the sixteenth-century indices.

45 Pierre Delsaerdt, 'A Bookshop for a New Age: The Inventory of the Bookshop of the Louvain Bookseller Hieronymus Cloet, 1543', in Lotte Hellinga et al., The Bookshop of the World. The Role of the Low Countries in the Book-Trade, 1473-1941 (Goy-Houten: De Graaf, 2001), pp. $75^{-86 .}$ 
refuge in the ambiguities arising from conflicts between the numerous indices of forbidden books. The religious orders also, equally predictably, protested any encroachment on their right of self-regulation: they insisted on the right to conduct their own surveys. This was conceded, but the terms of the survey were also made much broader. The Roman authorities now asked the religious orders to send the lists of all their books, not just forbidden ones, held in monasteries and cloisters or personally owned by monks or friars. The Congregation of the Index also insisted on the rules for the compilation of inventories: they must include not only the author's name and the title of the work, but also indicate the language, place of printing, printers and year of publication.

This is of course bibliographical gold dust. Carried out between 1597 and 1603, this snapshot of Italian religious collections constitutes what one historian has called as "the biggest national bibliography of the Counter-Reformation". ${ }^{46}$ The resulting manuscript lists, mostly deposited in the Vatican Library, comprise approximately 19,000 handwritten pages. They report on more than 9,500 libraries owned by 31 different religious orders. Between them these inventories list between eight hundred thousand and one million items. ${ }^{47}$

These materials have in the last years been the subject of a painstaking investigative study, the collaborative project Ricerca sull'Inchiesta della Congregazione dell'Indice (RICI) ${ }^{48}$ Although not yet complete, enough work has been done to demonstrate the potential of this sort of material. We can assess which were the most popular titles, and compare the numbers logged in the sixteenth century collections with the number of surviving copies today. We can assess whether the Italian monasteries were adequately supplied with books from Italian presses, or whether they bought many books published abroad - for instance in Paris or Lyon. But we can also find a lot of books that do not seem to be identifiable as any presently known editions.

46 Romeo De Maio, 'I modelli culturali della Controriforma. Le biblioteche dei conventi italiani alla fine del Cinquecento', in Romeo De Maio (ed.), Riforme e miti nella Chiesa del Cinquecento (Naples: Guida, 1992), pp. 355-370, p. 363 .

47 Roberto Rusconi, 'I religiosi e i loro libri in Italia alla fine del secolo Xvi', in Rosa Marisa Borraccini, Giovanna Granata and Roberto Rusconi, 'A proposito dell'inchiesta della S. Congregazione dell'Indice dei libri proibiti alla fine del'50o', Il capitale culturale, 6 (2013), pp. 13-45, at p. 15 .

48 See especially now the essays in part three of this volume. For an introductory description of the project and a sample investigation, Flavia Bruni, 'The book inventories of Servite authors and the survey of the Roman Congregation of the Index in Counter-Reformation Italy. From instrument of censorship to bibliographical resource', in Malcolm Walsby and Natasha Constantinidou (eds.), Documenting the Early Modern Book World. Inventories and Catalogues in Manuscript and Print (Leiden: Brill, 2013), pp. 207-230. 
These records need to be treated with some subtlety, as Roberto Rusconi here makes clear. ${ }^{49}$ Particularly when dealing with volumes that contained several titles, the visitors could be a little slapdash. Sometimes they would create a sort of pantomime horse by darting from the title at the beginning of a volume to a colophon at the end, ignoring the fact that there were several books in the volume. Thus they create a hybrid title, made up of the details of two quite different texts. But the RICI researchers are alert to these possibilities, and their careful, cautious work has resulted in the recovery of many books lost since the sixteenth century. The full richness of this material is made clear by the several contributions included in this volume. ${ }^{50}$

\section{Bestsellers}

So much, for now, for the information on lost books that can be extracted from contemporary official documentation: account books, documents of regulation and registration. Let us now turn to the books themselves. There are several ways in which we can follow the trace of lost books in other surviving books.

One very obvious category is re-issues and reprints. When a book is published in Paris stating on the title-page that it is reproduced "after the copy published in Rouen by Martin le Mesgissier" we may be fairly confident that this is a real (rather than invented) original that may no longer survive. The same is true of cases where the title-page of a book claims to be the third edition and the first or second appears no longer to be extant. This is exceptionally valuable information, since the books that went through multiple editions often fell into areas of the book trade particularly vulnerable to attrition. These included popular devotional texts, instructional manuals or language primers.

These sort of texts are also, as it happens, extremely well represented among the books for which advertisements were placed in the early Dutch newspapers. Thus the popular devotional text Het lof des Heeren, edited by Jacob Trigland, and offered for sale in Amsterdam by Marten Jansz Brandt in 1642 is advertised as the ninth edition..$^{51}$ Only two of these previous eight editions have currently been identified. The previous year Brandt published the fifth edition of Charles Drelincourt, Gebeden ende Meditatien om sich te bereyden tot

\footnotetext{
49 Chapter 14, below.

$50 \quad$ Chapters 12 to 15 .

51 Broer Jansz, Tijdinghen uyt verscheyden Quartieren, 1642, no. 43 (25.10.1642).
} 
het H. Avontmael, but a copy of only one previous edition has survived. ${ }^{52}$ Meynert Semeyns's short description of the herring fishery, published in 1639 was the fourth edition, but the first to survive. ${ }^{53}$ This is really invaluable information for one of Europe's most vibrant book markets, where short popular texts could find a sufficiently large market to sell out within a year, justifying the expense of taking advertisement space to publicise a new edition. These were books which were far more likely to have been appreciated by contemporary users than by those building a library. For evidence of their popularity we are therefore almost obliged to look beyond the corpus of surviving copies. Such an investigation turns up an astonishing amount of new material for the seventeenth-century Low Countries; the potential for similar investigations in other national print domains is demonstrated by the contributions of Rosa Marisi Borraccini and Giovanna Granata in this collection. ${ }^{54}$

\section{Music}

With music books the opposite was the case: these were books with a rather narrower and more circumscribed market, defined by high initiation costs and expensive both from the producer and consumer point of view. Large parts of this market were controlled by a small number of publishers, since the publication of books with musical type required considerable skill, as well as the investment to procure the necessary special fonts for the printing of musical notation.

Despite these forbiddingly high entry costs, the production of books of music became a flourishing and important part of the early modern book world. During the sixteenth century several thousand titles were published of four or five part arrangements intended for performance by choirs or in domestic settings. For the convenience of the singers the separate parts were printed in separate books. Although these were expensive books, rates of survival are very low: not unusually for books which were heavily used. Often these musical imprints survive only in bound collections now in specialist music libraries. These bound volumes often contain the alto or bass part of a sequence of different books. It may be that the other parts cannot be traced at all. In these cases it is straightforward to predicate the existence of absent superius or tenor parts. Replicated across the corpus, this allows the recovery of several thousand lost books. In passing it is worth remarking that several major bibliographical

52 Jan van Hilten, Courante uyt Italien, Duytslandt, \&c., 1641 no. 42 (19.10.1641).

53 Jan van Hilten, Courante uyt Italien, Duytslandt, \&c., 1639, no. 51 (17.12.1639).

54 Chapters 13 and 15 . 
projects persist in regarding the separate parts of these publications as a single bibliographical item. ${ }^{55}$ Yet in bibliographical terms these were quite separate publications, each with their own title page and collation, and have to be regarded as such, even if they were intended to be used together.

The collection history of books with music, whether intended for liturgical or recreational purposes, was very particular. Iain Fenlon's careful study of liturgical texts owned by Spanish Cathedrals reveals many items that are now extremely rare, and often, where the record is a contemporary inventory, known only from this fragile manuscript source. ${ }^{56} \mathrm{~A}$ high proportion of the musical part books that have come down to us today have done so because they made their way into a royal or ducal library, and were therefore preserved. It was not that these princely courts were the only markets for such books, more that these were the places they were most likely to survive. Thus the history of lost books is inevitably intricately bound up with the history of contemporary collecting; what records we have documenting such collecting practice must therefore form part of our scrutiny.

\section{Building a Library}

The dawn of print opened a new era in the history of collecting. Books became both abundant and affordable: individuals who in the manuscript age would have owned no more than a handful of books could now aspire to assemble considerable collections. By the end of the sixteenth century some private collections extended to many thousands of books.

Recovering the history of this collecting is now extremely challenging. Building a library was the work of a lifetime; but preserving the collection after the death of its creator was well nigh impossible. For many heirs the much cherished library was more of a burden; treasured and carefully assembled collections were soon dispersed, lost or sold. Sadly, few collectors were as assiduous in documenting their books as they were in seeking them out, which is why the rare exceptions, including the cases studied in the volume, are so very valuable. With these book lists we can begin to reconstruct the mental world of these owners, and this is the purpose to which such documentary material is mostly put. ${ }^{57}$ To identify from these inventories the actual edition a collector

\footnotetext{
55 See, for instance, VD16.

56 Chapter 4, below.

57 The genre is most comprehensively explored in Malcolm Walsby and Natasha Constantinidou (eds.), Documenting the Early Modern Book World. Inventories and Catalogues in Manuscript and Print (Leiden: Brill, 2013).
} 
owned can be far more challenging. As a rule these lists are not normally furnished with sufficient bibliographical detail to link the contents to particular editions, particularly when they relate to books published in many editions. This is even more the case with lists compiled after the death of the first owner. The main purpose of such inventories was valuation, and in assessing the retail value of such property, books were treated much like furniture. The size of the book and the quality of the binding played as significant a role in arriving at a valuation as the contents of the text. The description of the book itself was often perfunctory: the name of the printer, for instance, was usually only mentioned if the press was sufficiently distinguished to materially impact the resale value (the Aldine press, for instance, or books published by Plantin or Estienne). This lack of specificity in recording the edition owned is the main reason why it has proved so difficult to link information in major resources of testamentary information like the Private Libraries of Renaissance England database to our USTC as we would like ideally to do. 58

Probate inventories are particularly frustrating in their tendency to bundle small works: of little value so not worth the effort to enumerate separately. Thus the works most vulnerable to loss, and often the most interesting indications of the owner's personality and recreational tastes, are not separately listed; the main part of these collections, the books carefully valued, are otherwise heavily slanted towards professional use. ${ }^{59}$ Rather more can be gleaned from a class of document that emerges in the seventeenth century, auction catalogues, since these often include far more in the way of specific bibliographical detail. ${ }^{60}$

Most valuable of all are catalogues compiled by (or more usually, for) rich collectors; this was especially so if they hoped these collections might be preserved after their death for the common good. The collection of Sir Hans Sloane, described by Alison Walker here, was remarkable both for its extraordinarily comprehensive collection of medical books, and for its eclectic extension into different branches of printed ephemera. Sloane owned remarkable collections of both medical advertising literature and academic dissertations.

$5^{8}<\mathrm{http} / /$ plre.folger.edu/>.

59 E.S. Leedham-Green, Books in Cambridge Inventories: Book-Lists from Vice-Chancellor's Court Probate Inventories in the Tudor and Stuart Periods (Cambridge: Cambridge University Press, 1986).

6o Karel Bostoen et al. (eds.), Book Sales Catalogues Online. Book Auctioning in the Dutch Republic, 1599-ca. 180o: <http://www.brill.com/products/online-resources/book-sales -catalogues-dutch-republic-online $>$. 
This form of scholarly ephemera is among the least well documented parts of the European book world. Disputations and dissertations published by students and professors in Europe's expanding universities provided valued commissions for Europe's printers, and the reconstruction of this market has never really been attempted. These are books lost in the most extraordinary way that is, safely stowed in many of Europe's major libraries, but largely uncatalogued, and, indeed, beyond the reach of any conceivable cataloguing project. Several of Europe's major libraries have many thousands, in some case hundreds of thousands of such publications, which must for the moment count as functionally lost, even though their physical location is not in doubt. A major initiative may be required to recover this important part of the publishing industry and of early modern intellectual culture. ${ }^{61}$

\section{Modern Destruction}

With all of these different resources we are beginning to create a typography not only of survival, but also of loss. Most early printed books that survive, particularly those that survive in many copies, do so because they were collected and preserved close to the date of publication. There were probably not very many works published by William Caxton that have disappeared altogether, because he was recognised as collectable very early. ${ }^{62}$

With broadsheets and many small pamphlets the opposite was the case. Many small texts - particularly almanacs with a limited shelf life, and educational texts - were used and discarded close to their date of publication (often in the case of educational texts, with great relief by their young owners). Polemical pamphlets on political or religious subjects often survive rather better, because they were bound together in collections and made their way into libraries. They often survive in a larger number of copies, though here we really do need to examine the actual books to reveal what frequently turn out to be variant editions, rather than two copies of the same book. Official print was different again: posted up, distributed and only occasionally systematically filed away.

Even in the case of books that made their way into libraries, fire, flood, bombs and neglect can subvert the best laid plans. Some of the cruellest losses

\footnotetext{
61 Douwe B. Breimer et al., Hora Est! On Dissertations (Leiden: Leiden University, 2005).

62 Though an unrecorded indulgence, cut up for quire guards in a volume now in the possession of the Library of Congress, was discovered as recently as 1980. See Needham, The Printer and the Pardoner.
} 
have taken place in the last two hundred years. In 1870 the National Library of Strasbourg was razed to the ground by German bombardment, the priceless collection replaced, in a gesture of sly penitence, with duplicates contributed by German collections (creating what is now a largely Germanic collection). The collection of the University of Louvain was lost in 1917 and again in 1940. The German assault of 1940 and the allied invasion of France in 1944 claimed the libraries of Beauvais, Calais, Chartres, Douai and Tours. ${ }^{63}$

These losses were severe, but in terms of scale dwarfed by the enormous destruction and churning of the German printed heritage during the last years of the war and subsequent Soviet occupation (explored in this volume by Jan Alessandrini). ${ }^{64}$ The State Library of Berlin still does not know which of its books have survived, and where they might have gone. Some are certainly in Kraków, a partial restitution for the destruction of the library of Warsaw in 1944, and an unknown quantity in St Petersburg. The Soviet occupiers and the satellite states of Eastern Europe no doubt regarded this as small recompense for the terrible losses suffered during the period of Nazi aggression, which in the Polish case amounted to an attempt at the eradication of a national culture. ${ }^{65}$

War is not the only hazard. The royal library in Stockholm went up in flames in the eighteenth century, consuming many of the books plundered by Swedish armies during the Thirty Years' War. Other war booty remains securely tucked away in the University of Uppsala. ${ }^{66}$ As recently as 2003 an electrical fault left the baroque Anna Amelia Library in Weimar gutted. In 2009 the building of a new underground line caused the collapse of the City Archives in Cologne.${ }^{67}$ In 2014 the library of the Glasgow School of Art, designed by Charles Rennie Mackintosh and universally regarded as one of his most exquisite works, went up in flames, along with all of its contents. In all of these cases, at least since the nineteenth century, the existence of printed catalogues document many

63 Lucien X. Polastron, Books on Fire, The Tumultuous Story of the World's Great Libraries (London: Thames and Hudson, 2007), p. 174. Hilda Urén Stubbings, Blitzkrieg and Books. British and European Libraries as Casualties of World War II (Bloomington: University of Indiana Press, 1993).

64 Chapter 21, with an exhaustive survey of the existing literature.

65 Poland lost more than 16 million volumes, $80 \%$ of its total stock, from public libraries during the Nazi occupation. Polastron, Books on Fire, p. 185, and the article by Tomasz Nastulczcyk in this volume.

66 Josef Trypucko, Michał Spandowski and Slawomir Szyller, The Catalogue of the Book Collection of the Jesuit College in Braniewo held in the University Library in Uppsala (3 vols., Uppsala: Uppsala Universitetsbibliotek; Warszawa: Biblioteka Narodowa, 2007).

67 Below, Chapter 24. 
editions now lost, and these too are included in our records: though with a recognition that some particulars, notably format, cannot be regarded as reliable.

This unreliability can be compounded by the conversion of these old print or card catalogues into digital records, a conversion routinely effected without re-examination of the books. We are perfectly aware that the methodologies described above, and the level of trust we repose in records compiled for quite different purposes, will have created some ghosts. But this number is likely to be quite small - and certainly much smaller than the number of ghosts we have eliminated in the course of our library visits. Most of these ghosts are created by twenty-first century cataloguing practice, in particular the desire of libraries to hurtle towards the creation of digital catalogues without sufficient care. In these cases a single false keystroke can create a unique book that never existed; books that then have to be eliminated by examination.

\section{Lost Books: Methodological Assumptions}

From a methodological point of view it now seems incontrovertible that the gain in recovering these lost books, which will cumulatively amount to many thousands of editions, far outweigh the dangers inherent in the working assumptions applied. The probability that a certain source - a book list, a printed reference or an official source - can be relied upon always has to be carefully weighed, and experience handling these documents is important too. We are also only too ruefully aware that our most diligent efforts will only recover a small proportion of what has not survived in physical form. But the effort is important, because the methods we have applied impact most particularly on classes of literature most susceptible to destruction: almanacs, cheap print, ABCs, indulgences, printed ordinances and ballads. It is only really in recent years that books of this sort have begun to be recognised as the bedrock of the industry, and their true significance in the cultural economy of communication has been acknowledged. ${ }^{68}$ When, forty years ago, German bibliographers began what became the VD16, their equivalent of the English Short Title Catalogue, they left out broadsheet materials. ${ }^{69}$ So, even more inexplicably,

68 In an expanding literature see especially Joad Raymond (ed.), Cheap Print in Britain and Ireland to 1660 (Oxford: Oxford University Press, 2011).

69 So, for instance, the broadsheet editions of Luther's 95 theses, one of the foundational documents of German culture, are not included in the German national bibliography. USTC 751649,751650 . 
did those who set up the Netherlandish Short Title Catalogue twenty years later. These lacunae have had to be painstakingly made good: with the extension of the coverage of the Universal Short Title Catalogue to 1650, it now contains records of at least forty thousand documented examples of single-sheet publications. ${ }^{70}$

To some extent all historical investigation involves the assessment of a balance of probabilities. When historians read a letter, let us say, from Sir Francis Walsingham in Paris to William Cecil in London, offering his first reaction to the St Bartholomew's day massacre, this is treated as a valuable first hand eyewitness account. We do not waste a great deal of time examining the possibilities that the letter might have been forged, or that Sir Francis was not actually in Paris. This is because these contrary possibilities are extremely remote: all historical scholarship is, in this respect, inherently probabilistic. ${ }^{71}$

The reticence in applying similar familiar techniques for the weighing of evidence to the field of material bibliography is all the more striking when we consider that other disciplines in the history of the book have embraced far more speculative strands of scholarship. I think here particularly of the freight attached to manuscript marginalia and annotations in the quest to assess reader responses to text. In fact in the vast majority of cases such marginalia are extremely unrevealing. ${ }^{72}$ We scarcely know whether an annotation signals assent or disagreement, or even which of a sequence of owners is making it.

My modest proposal to scholars of material bibliography is not to follow such researches into the field of the imagination, but merely to accept the probability that when careful contemporaries recorded the existence of a book, this book did indeed exist; and to act on that probability, rather than reject this specific class of evidence because of an absence of certainty. For the gains of adjusting our perceptions in this manner are potentially massive. Once we obtain, in so far as we can, a more holistic view of what was printed, we will understand far better the constraints and motivations that governed the choice of particular texts. A printer fed a reliable stream of commissions from the local bishop or town council was far less likely to dabble in forbidden

70 A survey of the existing state of knowledge, with a first attempt to offer a quantitative analysis, is Andrew Pettegree (ed.), Broadsheets. Single-Sheet Publishing in the First Age of Print (Leiden: Brill, 2017).

71 For reflections on the applications of probability to a wide range of intellectual areas see now Nate Silver, The Signal and the Noise (New York: Penguin, 2012).

72 Ann Blair, 'Errata lists and the reader as corrector', in Sabrina Alcorn Baron et al. (eds.), Agent of Change: Print culture studies after Elizabeth L. Eisenstein (Amherst: University of Massachusetts Press, 2007), pp. 21-41. 
or sensitive publications, a lesson well learned in Ancien Régime France. Keeping printers busy and rich was a far more effective assurance of loyalty than any regime of censorship. Robert Darnton's Forbidden bestsellers were published abroad not because the control of French printing was particularly oppressive, but because French printers preferred not to jeopardise their existing business. ${ }^{73}$ We are reminded once again that the greatest threat to freedom is not censorship, but conformity. To understand the economy of print is not to turn one's back on the world of ideas. It is a necessary prerequisite to understanding that world.

73 Robert Darnton, The Forbidden Bestsellers of Pre-revolutionary France (New York: Norton, 1995). 